\title{
City Profile: The Bogotá Metropolitan Area That Never Was
}

\author{
Luis A. Guzman \\ Departamento de Ingeniería Civil y Ambiental, Universidad de los Andes \\ Edificio Mario Laserna Cra $1^{\circ}$ Este N 19ạ-40 Bogotá, Colombia: Tel (+571)3394949 \\ la.guzman@uniandes.edu.co \\ Daniel Oviedo \\ Development Planning Unit \\ University College London \\ Gower St, London, WC1E 6BT \\ d.oviedo.11@ucl.ac.uk \\ Juan Pablo Bocarejo \\ Departamento de Ingeniería Civil y Ambiental, Universidad de los Andes \\ Edificio Mario Laserna Cra $1^{\circ}$ Este № 19ạ-40 Bogotá, Colombia: Tel (+571)3394949 \\ jbocarej@uniandes.edu.co
}

\begin{abstract}
Bogotá's urban and regional planning has focused on pressing demographic, economic, and urban development needs that can no longer be administered without a comprehensive understanding of its surrounding region. Population growth in municipalities in the vicinity of Bogotá is twice that of the city, which in some cases has led to a functional integration and conurbation as part of the same territory, despite having different governments and uncoordinated urban development plans. This paper revisits the evolution of the governance and regulatory framework of Bogotá and its surrounding region, as contrasted with the spatial and socioeconomic aspects at the larger metropolitan scale, and analyses its effects on the current configuration of the city-region that we identify as the Bogotá Metropolitan Area. The paper draws conclusions from primary and secondary information, providing insights into the recent and future development of the city and its metropolitan area that is yet to be officially constituted.
\end{abstract}




\section{Introduction}

Bogotá, the capital of Colombia, has become a paradigmatic case in the study of urban development in the Global South. This can be attributed to both significant examples of efficient urban management by some previous local administrations (Dávila 2009, Dávila, Gilbert et al. 2006), and to innovations in urban infrastructure and services that are regarded internationally as best-practices, such as local Bus Rapid Transit (BRT): Transmilenio (Gilbert 2008, Hidalgo, Sandoval 2004).

In a previous city profile, Skinner (2004) provides a comprehensive review of almost fifty years of changes in the physical, social, and governance layout of the city, up to the end of one of the most relevant periods for local urban development: the two governments of Mayor Antanas Mockus and the administration of Mayor Enrique Peñalosa. Today, 14 years after his first period as Bogotá's mayor, Enrique Peñalosa has been re-elected to running a city that has seen many changes in its spatial, functional and institutional dimensions. This is therefore a pertinent time to revisit some of the spatial, economic and social aspects of Bogotá from a broader perspective that incorporates the larger metropolitan scale of the city.

During the last 30 years the population of Bogotá has multiplied by 1.9 , while in the city's surrounding areas this growth has been 2.8 times. This paper examines the demographic, economic and spatial dimensions of the recent evolution of what we term the metropolitan area, paying special attention to the regional dynamics. This growth has occurred despite the lack of a regional authority for urban management. Our data allows us to identify the location of main urban activity centres, tendencies of urban population distribution, and functional interactions of the city-region, reflecting on the implications of the emerging urban form for local urban governance, economic, and social development.

\section{Governance, demographic growth and geographical features}

The current governance structure of Bogotá's metropolitan area (or BMA, as the operative acronym we use in this paper) is partly a consequence of Bogotá's administrative, spatial, urban, and socio-economic structure, which has been consolidated by processes of institutional reforms that had decentralisation and administrative reorganisation at their core. Such processes can be traced back to the mid-twentieth century.

\subsection{Milestones in Bogotá's growth in the late 20th century}

Initial steps toward the administrative reorganisation of the capital territory were characterised by the adhesion of municipalities adjacent to Bogotá. Such reorganisation deeply influenced not only the urban growth of the city, but also its institutional arrangements for the provision of essential services such as transport and utilities.

In 1954, during the de-facto military national government of General Gustavo Rojas Pinilla (1953-1957), Bogotá experienced the first institutional process of the absorption of neighbouring municipalities, which ultimately became part of the current structure of the city. By presidential decree, six neighbouring municipalities (Usaquén, Suba, Engativá, Fontibón, Bosa, and Usme) were annexed to Bogotá city, giving birth to the Special District of Bogotá that later became the modern Capital District (D.C). This process sought to respond to increasing pressure for more efficient urban management of Bogotá's territory and its immediate surroundings due to rapid demographic and physical growth, and to the limited 
capacity of local governments in these municipalities to provide adequate utilities and essential services (Botero, Suárez 2010). This first step towards decentralisation permitted a clear definition of an administrative division of the city in zones that preceded the current administrative division. Such zones marked the redefinition of the city's administrative structure, including what until that time had been independent adjacent municipalities.

Dávila (2005) and Botero and Suarez (2010) argued that the reforms that joined together Bogotá's neighbouring municipalities in the mid-1950s were motivated by demographic, political, and administrative concerns related to the definition of a space that could adapt to future pressure for the physical and population growth of the city. This called for a rapid expansion of existing networks of infrastructure and urban services in order to provide connectivity to the new areas and to integrate them into the city's functional and economic structure. Unfortunately, these motivations were not interconnected and this led to fast urban development and pressing demands for the supply of infrastructure, housing and services without sufficient involvement from the public sector. The new city neglected the need to develop a master plan and ignored regional considerations, despite previous attempts to develop regional master plans for the city. Lack of a long-term planning culture allowed growth decisions to remain in the hands of all sorts of developers, including a large number of emerging informal housing developers. These developers began to build precarious low cost housing in the peripheries of growing municipalities in the region without connectivity to electricity, water and other utilities, and public services or infrastructure (Cortés 2005). According to Dávila (2005), between the 1950s and the 1990s, the population of Bogotá grew to almost ten times its original size, whereas its built area grew at a somewhat more moderate pace from $4,000 \mathrm{Ha}$ to $29,000 \mathrm{Ha}$, positioning itself as one of the densest cities in the region. Since the 1950s no further initiatives to incorporate surrounding municipalities into Bogotá or to constitute a unified authority for the metropolitan area have come to fruition.

The evolution of planning in Bogotá and its surrounding region is a reflection of this lack of integrated regional initiatives and governance. Earlier initiatives for coordinating the development of Bogotá included all-encompassing master plans for a controlled growth of the city and its adjacent region. Renowned architect, Le Corbusier, developed a modernist master plan in 1951 that introduced the idea of a multipolar regional network for Bogotá and some of its surrounding territories. This, however, was not put into practice beyond the pilot phase. In 1961, through the Pilot Road Plan, Bogotá's administration developed the first plan for road infrastructure that built on technical studies and appraisals rooted in planning approaches that had been developed in the United States and Europe, known as the Urban Transport Planning Process (Montezuma 2000). This plan revisited some elements of Le Corbusier's master plan, introducing ring roads and a mixed road network for the city. Some of the most relevant road corridors in the city today are a result of the implementation of this plan, of which $60 \%$ was completed and were one of many attempts to define a ring road that served as an outer boundary for controlling Bogotá's growth. One of the most emphatic recommendations of the plan was the construction of an urban rail system for public transport that supported dense development and improved the connectivity and consolidation of the existing city. However, this was discarded in place of what at the time was perceived as one of the main priorities for urban development: road infrastructure (Montezuma, 2000).

Several main roads were built in the city in the 1960s as part of a modernisation process that involved its adaptation for the era of the car. Later, in 1972, Lauchlin Currie revisited some of the ideas set out in Le Corbusier's plan at the regional scale, introducing in a study entitled "Fase II", what Acosta (2010) identifies as: "development alternatives and the necessary support networks required to face the demographic explosion expected at the 
time". Like its predecessor, this plan was not implemented. However, it provided insights for subsequent sectorial agendas. Recent initiatives, reviewed later in this paper, have picked up the need for metropolitan planning for Bogotá and its surrounding municipalities. However, during the last decades of the twentieth century the pressure to address the city's immediate problems led to planning initiatives and projects with an internal and sectorial focus. In recent years Bogotá's own urban development and governance has been framed by the lack of a metropolitan authority. Despite the significant progress made in relation to modernising Bogotá's government and urban structure during the last decade of the 1900s and the first of the 2000s (Gilbert 2008, Hidalgo, Sandoval 2004), over the last decade the city's administrations have faced different challenges related to mismanagement, corruption, and pressing internal urban needs that have placed regional development in second place. Although during the first part of the 21 st century the city witnessed changes in public policies related to civic culture and positive behaviour, large investments in infrastructure and public spaces, as well as progress in social programmes, more recent governments have left the city with considerable challenges in relation to urban transport, land-use planning, and financial management that may impair future initiatives for regional integration.

\section{2 "Building" an unequal city-region: imbalances at different scales}

Recent urban literature argues that Latin American cities, and in particular their metropolitan regions, show an increasing socio-economic mix at the macro level and increasing segregation at the micro level (Janoschka, Borsdorf 2006, Coy 2006, Libertun de Duren 2006). These patterns of segregation can have potential long-term social consequences, particularly in relation to the increase in social and spatial inequalities within urban societies (Libertun de Duren 2006). Bogotá, like other large metropolises in Latin America, has not been able to contain its growth within its existing boundaries, spilling over into smaller towns and adjoined settlements, while being restricted by its own jurisdiction (Halseth 2005, Nickson 1995). Thibert and Osorio (2014) argue that the socio-spatial segregation of Bogotá's metropolitan region not only has immediate social and economic consequences, but also long-term political repercussions. These political consequences can be linked to shifts in population belonging both to the economic elites and the poorest residents from the city centre to the peripheries, which may entail shifts in the distribution of power and strengthen inequalities in the distribution of public investment, infrastructure, and access to urban facilities and functions.

According to evidence from Watson (2009), class and income inequalities in the cities of Latin America and the Caribbean have deepened the gaps between rich and poor that place cities in these regions amongst the most unequal in the world. Low and Astle (2009) contend that "the particular capacities and powers of organisations influence transport planning outcomes". The case of the municipalities surrounding Bogotá contrast with others reported in the Latin American scientific literature where large municipalities embedded in prominent metropolises have demonstrated high performance and efficiency in urban planning and management. The shift of investment and speculation toward the peripheries allows both "increased suburban development by the upper and middle classes and more rapid consolidation by the peripheral poor" (Carter 2003). Transport infrastructure plays an essential role in these trends, both by facilitating the consolidation and homogenisation of the middle classes in suburban communities and allowing the establishments of the poor away from the city centre (Borsdorf, Hidalgo 2010).

Hurtado, Henández et al., (2014) argue that the urban management model in Colombia is closely related to the administrative decentralisation processes experienced in the country and to a definition of institutional frameworks that is very much centred in the municipalities. 
This generates a planning system that is strongly dependent on the localisation of power and, to a large extent, on the privatisation of public goods and services (Miranda 2008). Due to its demographic, political, and economic relevance, Bogotá has seen a number of reform initiatives since the 1950s that were ultimately ratified by the constitution and that were operationalised in a later law known as the Organic Statute for Bogotá D.C. (Estatuto Orgánico de Bogotá, Decreto Ley 1421 de 1993). Such reforms, conceived at either the local or national level, included plans, projects, or regulations that sought to organise the development of the city in subsequent years within the limits of the national legislation and planning systems that were already in place. In his profile of the city of Bogotá, Skinner (2004) suggests that Bogotá's economic primacy within the country motivated institutional, planning, and regulatory changes during the 1960s and 1970s. These changes were linked to the growth of the state and the growth of parastatals that were concentrated in the city during these decades, as well as the growth in commercial air transport. Salazar-Ferro (2007) argues that these changes largely responded to a top-down approach to city planning that intended to project national agendas and priorities at the municipal level. This not only resulted in initiatives that were generally limited to specific sectors and spatialities, but also to an increase in social and spatial inequalities in the city.

Initiatives within the national and local legislation introduced new instruments for decentralisation at the municipal level. In Bogotá, agreements produced by the city's council granted new powers and responsibilities to local administrations (Agreement 26 of 1972, Agreement 8 of 1977). In addition, new entities were created to administer different aspects of urban development. These included the creation of local administrative boards named Juntas Administradoras Locales (JALs), newly elected local government for each local government area that carried out local development works and monitored investments; the Urban Development Institute, a new institution responsible of public works; and a new department for administering transport in the city, these changes were accompanied by strengthening local utilities companies that organised their own planning offices (SalazarFerro 2007). According to Gilbert and Varley (1990), public infrastructure agencies in Bogotá had an outstanding performance during the 1960s and 1970s, reflected by a rapid increase in capacity, improved coverage and better servicing, particularly in the services of water, sewerage, and electricity within the boundaries of the city. However, regulations and administrative boundaries constrained the expansion of infrastructure networks to the larger metropolitan area of Bogotá, producing an imbalance in access to public services and urban functions between different municipalities.

One of the most relevant milestones during this time was the creation of the Urban Development Institute (Instituto de Desarrollo Urbano, IDU) in 1972, which is the institution responsible for public works in the city (Botero, Suárez 2010). Through this institute the city sought to increase efficiency in the management of road and public-space infrastructure by prioritising and focusing on road development programmes that would improve connectivity between rapidly growing areas of the city and its centre. In 1976, aiming to exert larger control over increasing private motoring and provision of public transport, the city created the Administrative Department for Public Transport and Transport (DATT) and assigned it the functions of planning, coordination, monitoring, and regulation of public and private transport, as well as regulating transport-related education and driving academies in the city (Agreement 11 of 1976).

Milestones of urban development and fragmentation between Bogotá and its surrounding municipalities were also influenced by the increasing flow of finance from international development agencies such as the World Bank and the IDB, which at the time were instrumental in the development agendas of many Latin American cities. However, as some 
of the main concerns were related to larger cities, smaller municipalities in the region received little attention from these agencies. Examples of programmes that received international finance from such agencies included zonal urban development programmes, named PIDUzOB I and II (Salazar-Ferro 2007). The first phase of these programmes, implemented during the 1970s, targeted an integral investment for the Eastern side of the city that included road and pedestrian infrastructure, investment in healthcare facilities, public spaces, utilities, social housing, and technical assistance. As a result of PIDUZoB I the city built the last large road corridor of the twentieth century, the Avenida Circunvalar. This not only opened the door for both formal and informal urbanisation of the mountains in the easternmost part of the city, but was also designed almost exclusively for the use of private vehicles, limiting connectivity by public transport (Montezuma 2000). PIDUZoB II was an ambitious programme targeting the area of Ciudad Bolivar, one of the main clusters of low-income population in the city during the last three decades. This addressed similar concerns to the previous phase, although it included larger investments on social housing and a set of specific actions and plans carried out by the city's planning department (SalazarFerro, García Bocanegra et al. 2010).

Some more recent processes of urban development in Bogotá can be found in transport development initiatives that have involved cooperation between public and private actors, as well as degrees of coordination between different scales of government, such as Transmilenio (Monzón 2005). However, such examples have also involved a considerable degree of local investment, understood in economic as well as technical, political, and logistics terms, highlighting the relevance of strong institutions at all levels of local government (Hurtado, Henández et al. 2014) and, in the case of Transmilenio (BRT system), not involving the surrounding municipalities to any significant extent.

\subsection{Recent urban management and development in Bogotá and the role of transport infrastructure}

The development of Transmilenio during the first Peñalosa government and the subsequent investment in the second Mockus' administration led to the consolidation of BRT as an instrument for reorganising urban transport in Bogotá (Skinner 2004), as well as considering for an integrated public transport system within the city's boundaries, and even for some routes connecting adjacent municipalities. In the election of 2003 the electorate voted for a left-wing candidate that advocated for the working class interests (Gilbert 2015). Alongside introducing more poor-centred programmes, Mayor Garzón's objective was not to introduce populist policies but rather to maintain those of his predecessors that had proven to be positive for the city. As such, his anti-hunger programme, child education and welfare, and the management of the city's finances were well received both during and after his administration. However, amongst Garzón's shortcomings, some of the most significant were the decline in security and the worsening quality of transport in the city. This marked the beginning of a longstanding decline in the transport system, which has continued up to today, and is characterised by overcrowded public transport, lack of maintenance and investment in roads, and reduced control over congestion and motorisation. Mayor Garzón, as well as previous administrations, was more concerned with the internal priorities in his agenda than he was with the larger urban and development landscape of the city (Gilbert 2015).

By the end of the first decade of the 2000s none of Bogotá's governments made any substantial effort towards regional integration and inter-municipal planning. The election that followed had further negative effects on the city's urban and functional structure. In 2008, Samuel Moreno won the election with support of the lower-income voters. Gilbert (2015) 
argues that this Mayor, coming from a history of service in the national senate, was prone to political influence, corruption, and clientelism. This led to a city government that compromised a large share of its autonomy by granting political favours and appointments in the administration. Laxity in the performance of officials appointed at agencies for monitoring and control led to illicit deals involving the city's officials, and corruption in major infrastructure and service contracts awarded between 2008 and 2011. As one of the most infrastructure-intensive sectors, transport was at the centre of corruption and illegality in the Moreno administration. Transmilenio's third phase, which was held back for most of Moreno's time in office due to his promise of building a metro for the city, was involved in one of the largest scandals of corruption because of commissions being paid to the Mayor and his brother by private contractors (Gilbert 2015). In 2012, after a transition administration appointed by the President following Moreno's incarceration, former Senator Gustavo Petro of the Progressive party was elected. The third in a series of left-wing administrations, Petro had aimed to reduce social inequalities and introduce new controls on urban expansion and sprawl in the city. Petro had a progressive agenda aimed at reducing the cost of transport services for the poor, increasing access to housing, increasing taxes for higher-income sectors, and he promised to deal with gun control and the problems of drug addiction (Gilbert 2015). However, his administration lacked experience, was contested from different sectors, and was even involved in residual scandals from the period dubbed by the media as the "carousel of corruption", during which different public officials were involved in money embezzling scandals related to civil works in Bogotá. This administration was one of the first to address regional issues, proposing substantial changes in land-use regulation or the POT (Plan de Ordenamiento Territorial). However, most of the initiatives of this Mayor were truncated before coming to full fruition.

\subsection{Latest initiatives for regional integration}

The concept of the metropolitan area in the Bogotá region is one that has gained increasing relevance in recent years. The governments of Bogotá and the municipalities, with support from the national government, have attempted, in different ways, to constitute a metropolitan authority for land-use and spatial planning (Acosta 2010). In 1994, initiatives to amend the Constitution in order to create a Special Administrative Planning Region (RAPE) for Bogotá, its surrounding municipalities, and an expanded set of provinces (or departamentos), faced strong political resistance that resulted in it being discarded. In the same year, the country adopted the Law for Metropolitan Regions, from which emerged the five metropolitan areas currently operating in Colombia. However, no agreement was possible for the Bogotá region (an alternative name for BMA), specifically because of political resistance to the creation of a new authority. Other initiatives lobbied by the provincial government, such as a Regional Planning Working Table supported with technical assistance from UNCRD-LAC in 2001, the promotion of Regional Development Scenarios in 2006, and the Regional Initiatives Agenda in 2007, have set a basis for future initiatives. In 2009, the Governor of Cundinamarca and the Mayor of Bogotá reached agreement to join efforts on a 23-point agenda, seeking the creation of a regional agency and a joint lobby for the RAPE proposal in Congress (Acosta 2010).

The differences in power and wealth among municipalities play a major role in the resistance from different actors involved in the region. With the constitutional definition of new powers for all municipalities introduced in 1991, local decision-makers and politicians enjoyed increased autonomy for decisions and investment, which could be threatened by the introduction of a new authority at the subnational level. In addition, a large share of municipal income comes from national transfers, whereas the subnational transfers only represent 
about $15 \%$. In this regard, the provincial government has limited power to lobby for regional integration as local governments tend to be wary of losing their power and income streams. The precedent of the annexation of the six municipalities in the 1950s has also induced reluctance among local governments toward the creation of a metropolitan area or their annexation to Bogotá. Were former municipalities to become merely Bogotá's local jurisdictions, their power and influence would significantly decrease as they would depend on the city government for policy and investment decisions. Conversely, officials in Bogotá can be reluctant to join certain municipalities given their high concentrations of poverty and informality, whilst failing to make any significant contribution to the city's economy or its tax revenues. Therefore, it has not been possible to reach an agreement for this metropolitan area to become a reality. Furthermore, a certain vagueness continues to surround the concept, particularly regarding its functional aspects.

Regional integration has not been a priority in Bogotá's governments during the past decades, and in many cases municipal governments have not approached the idea with sufficient energy. The extension of less than $10 \mathrm{~km}$ of the Transmilenio trunk line to Soacha, the most populous municipality in the vicinity of Bogotá, took almost 10 years due to institutional and regulatory limitations related to the absence of a metropolitan transport authority, lack of in-house capacity for planning in Soacha, and lack of sufficient funding. Completion was only possible after special allowances were made for the system's management agency to operate outside Bogotá's borders for this specific purpose (Acevedo, Velásquez et al. 2012). Thus, the BMA is, and will likely continue to be, a conurbation that is not officially constituted.

\section{Characterization of the BMA}

Despite the lack of a coordinated planning scheme, the structure defined for the city allowed Bogotá to have sufficient room to accommodate most of its expansion between the 1960s and the 1990s. The city's population grew from 330,000 inhabitants in 1938 to 1.69 million by 1964, reaching over 5.5 million in the mid-1990s without spilling over its defined borders (Villarraga 2015). With the issuing of Law 388 in 1997, Colombia adopted a zoning scheme for the planning and management of urban territory. Although different initiatives to this end had been proposed since issuing the Constitution in 1991, it took twenty years for the national law of land-use to become a reality (Ministerio de Ambiente, 1998). The law states that every municipality with a population over 100,000 inhabitants must issue a Land-Use Plan or POT (Plan de Ordenamiento Territorial), which governs physical development through clearly established rules and regulations. According to the National Planning Department (DNP), the POT is the route chart for urban development in the country and can limit articulation between adjacent municipalities in the absence of a metropolitan authority.

Acevedo, Velásquez and Bocarejo (2012) argue that Bogotá formulated its POT from an exclusively internal perspective, setting down the foundations for the fragmentation experienced by the capital region in the following years. This is not to dismiss the achievements of the city's POT. Given its rate of economic growth in recent years, the city needed to steer its development to provide the required capacity for efficient economic production and the social development of its rapidly growing population. Considerations of densities, land-use, development and recovery of public spaces, and the provision of lowcost housing, to close the gap between demand and supply, are relevant milestones in the development of the plan. However, scarcity of land for urban expansion and lack of adequate instruments for control of land value, capture of the economic benefits of transport infrastructure investments, and mechanisms for redistribution of the benefits has led to 
increased land prices even in low-income areas. This makes it increasingly difficult to locate housing for low-income families within the perimeter of Bogotá.

\subsection{Composition of the BMA}

According to the National Statistics Department, the BMA, understood by national statistics as a functional but not legal or administrative unit, is composed by the city of Bogotá and the municipalities of Soacha, Sibaté, La Calera, Sopó, Tocancipá, Gachancipá Zipaquirá, Cajicá, Tabio, Chía, Tenjo, Cota, Funza, Mosquera, Madrid, Facatativá and Bojacá (see Figure 1). According to Bogotá's Urban Planning Office (SDP), in 2011 the city of Bogotá comprised of 7.46 million people in an area about $365 \mathrm{~km}^{2}$. The surrounding municipalities do not have a unique institutional organisation; each of the contiguous municipalities still makes autonomous decisions. As argued earlier, these areas extended across 2,272 km² with a population of 1.23 million inhabitants. In 2011, this data makes the BMA the largest metropolitan area in Colombia, one of the largest in Latin America and one of the 25 most populated urban centres in the world. For the purpose of this study, the urban area of the BMA was divided into 129 zones: 112 "zonal planning units" (UPZ) in the city of Bogotá and each of the municipalities treated as a unique zone.

The interactions among these zones have a close functional relationship that derives from their urban dynamics. Considering the intensity of the relationship, the SDP has established three categories:

1. First ring: comprising the municipalities of Cajicá, Chía, Cota, Funza, Mosquera, Madrid, Soacha and La Calera.

2. Second ring: comprising the municipalities of Gachancipá, Tocancipá, Sopó, Tenjo, Tabio, Bojacá, Sibaté, among others.

3. Third ring: sub regional centres, including the municipalities of Zipaquirá and Facatativá.

The municipalities close to Bogotá have different integration levels with the city. Soacha is the only municipality that is fully integrated into the city. Mosquera, Funza, Chía and Cota have varying degrees of urban or suburban integration with an important industrial activity. 


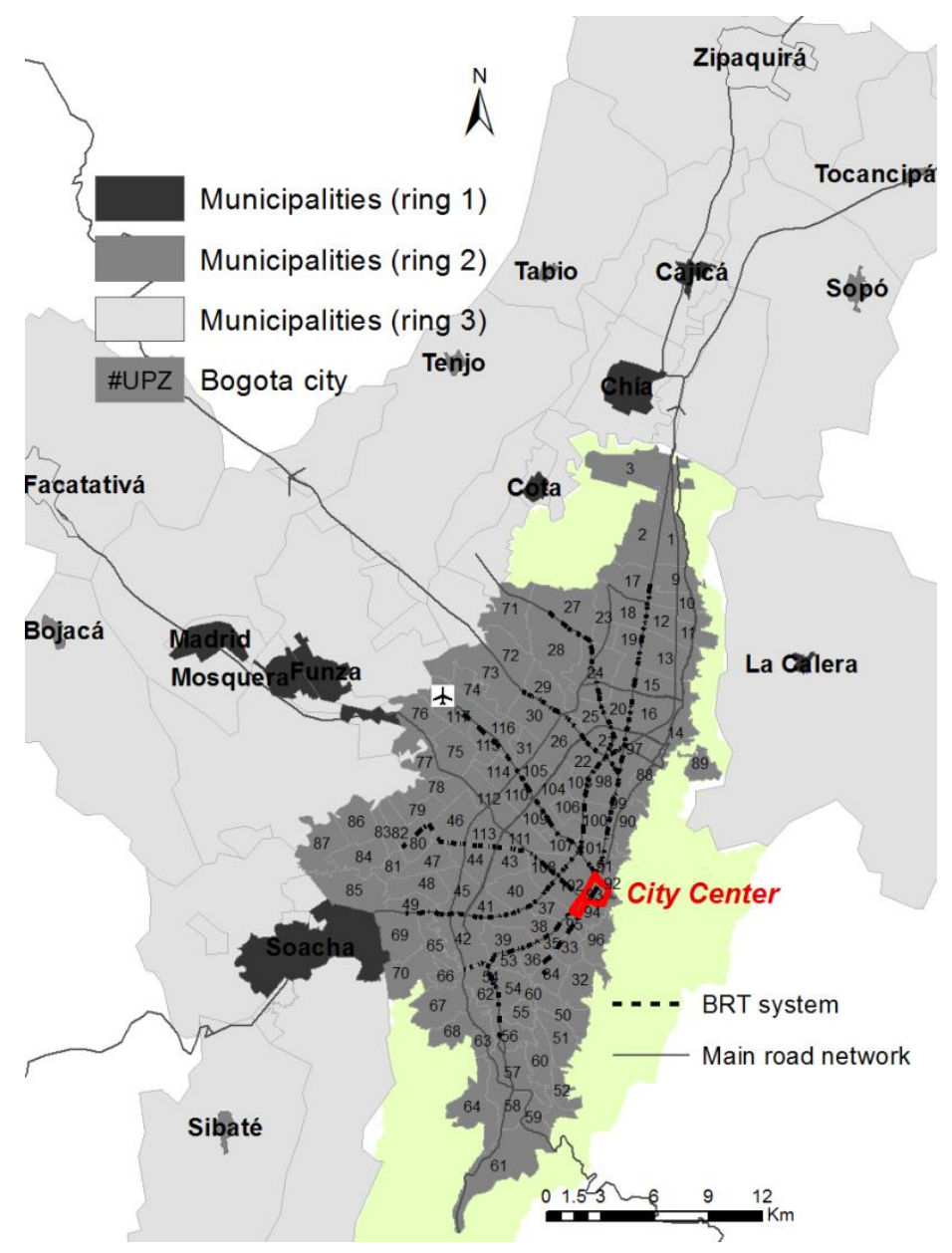

Figure 1. Bogotá region (municipalities and Bogotá City)

Source: elaboration by the authors

\subsection{Economic output and employment}

Bogotá and its surrounding region contributed 32\% of the national GDP in 2012, which amounted $31 \%$ of national industrial production and a large share of the service sector (DANE 2013). This places the region at the centre of the national economy. During the 1990s and early 2000s, Bogotá's per capita GDP was considerably higher than the average for the rest of the country ${ }^{1}$. In addition, up to 2005 , Bogotá's economy experienced faster growth in comparison with the national economy. As shown in Figure 2, the economic behaviour of Bogotá is intimately related with the national economy, reflecting very similar tendencies in per capita growth. Although economic growth in the city has been moderate in comparison to previous years, it has remained stable with local production restructured towards a higher focus on the service sector. The region's current economic activity is mainly concentrated in small and medium-sized businesses (85\%), the largest share of which is located in Bogotá (Pardo, Alfonso 2013, World Bank 2009).

\footnotetext{
${ }^{1}$ Bogotá's per capita GDP was $61 \%$ higher than the national average in 1995 and $49.9 \%$ higher in 2000.
} 


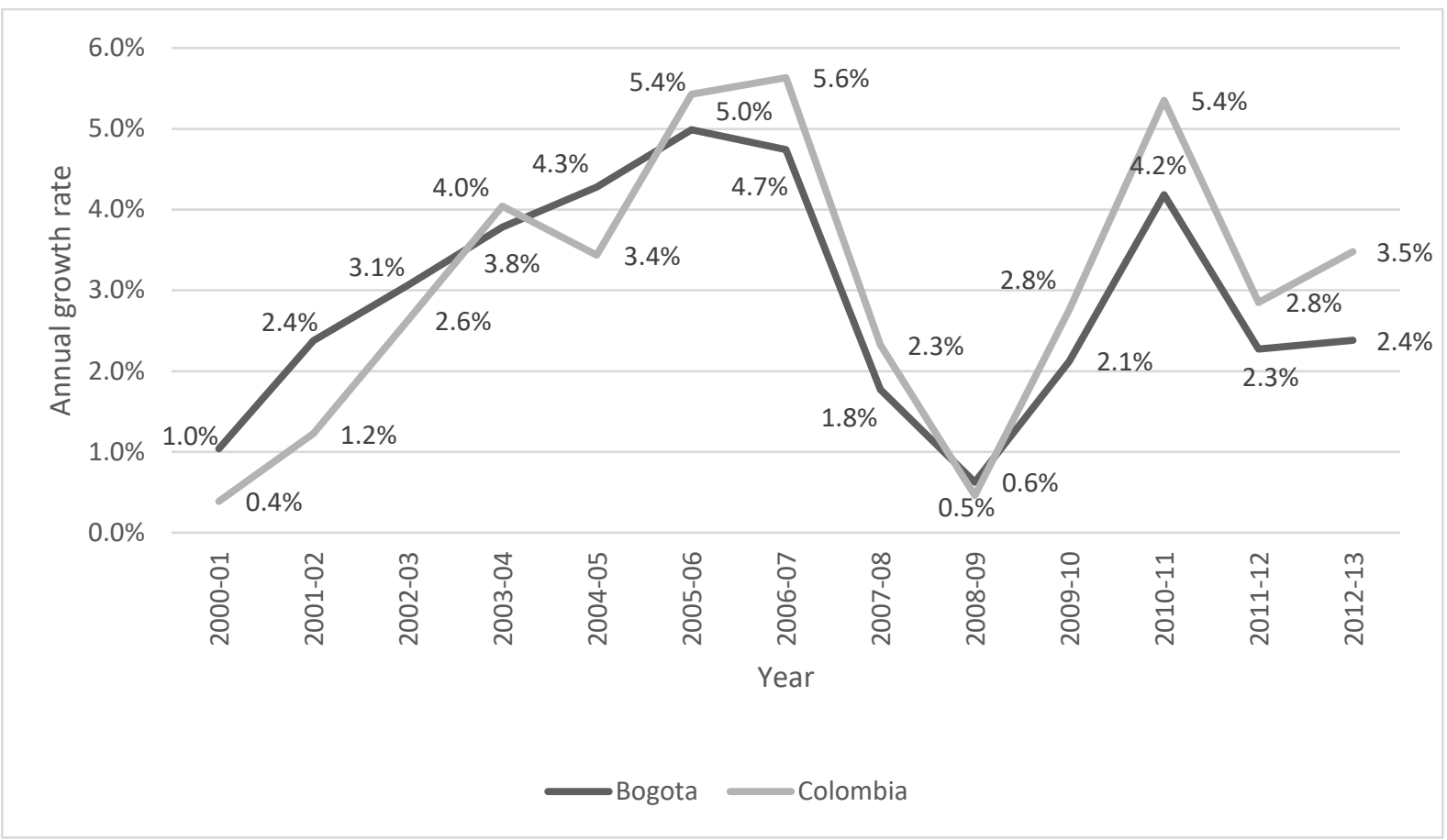

Figure 2. Rates of growth in GDP per capita for Bogotá and the rest of the country Source: Angulo Salazar, Díaz et al. (2013)

The evolution of the city's economy has led to the strengthening of specific sectors, which is evidenced by the change in its structure of production. Between the late 1980s and 2013 the share of finance, insurance, and real estate in the economic production of the city increased from $20 \%$ to $33 \%$, whereas manufacturing experienced a sharp decline in the same period, decreasing from $25 \%$ to $10 \%$. Commerce remained relatively stable in the economic production of the city, increasing from 11\% to 15\% between 1989 and 2013 (DANE 2013).

The restructuring of the city's economic production has influenced the distribution of employment by sectors, decreasing the percentage of employment positions in manufacturing (see Figure 3). This is not to say that employment in the city has reduced. On the contrary, by 2008 unemployment in the city was below 12\%. Data from the National Statistics Department shows that the number of unemployed in the city decreased from 610,000 to 403,000 between 2001 and 2013 (DANE 2013). However, there has also been a great increase in the amount of informal and inadequate employment in relation to skills. There is a mismatch between the structure of the job market and the skills of the general population, affecting particularly low-income and in-migrant groups. The current structure of the local economy and slower economic growth poses difficulties for the generation of new formal employment in the city, increasing the effect of informality on the city's economic structure (Angulo Salazar, Díaz et al. 2013). 


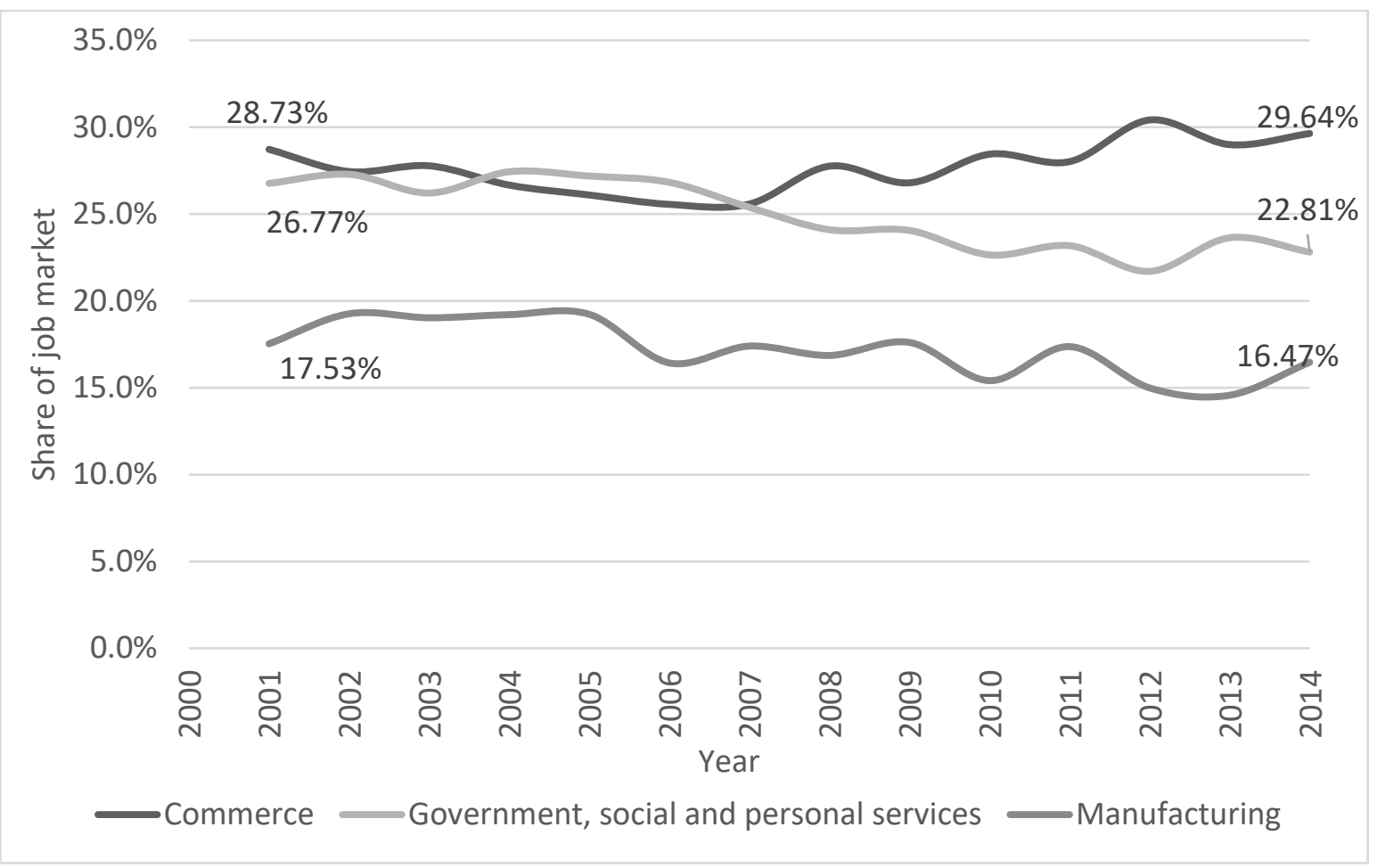

Figure 3. Job market distribution by sectors

Source: DANE (2013)

Bogotá is the main centre of employment in the country, supplying around 4.1 million jobs in the formal sector in 2013; enlarged by approximately 1.87 million informal employment jobs (DANE 2013). However, the spatial configuration of Bogotá concentrates most of the job market along a biaxial CBD located at the centre of the city.

From an economic analysis of the BMA it is possible to demonstrate the unequal distribution of the economy in the region. Indeed, those municipalities that are closer to Bogotá can maximise economic relations that contribute to regional economic growth. Figure 4 (left) shows the GDP per municipality (Bogotá is aggregated) in billions of COP in 2008 and it is evident that the municipalities that have greater wealth are closest to Bogotá. This information indicates, in an aggregate way, some statistics about the close economic relations of the closest municipalities with Bogotá. One consequence of this spatial distribution is the presence of an economic phenomenon of greater intensity in the municipalities adjacent to Bogotá, as compared to those more distant municipalities. This is reflected in the location of companies (see Figure 4 right). The proximity to Bogotá allows municipalities to maximise their economies beyond their natural area of influence. 


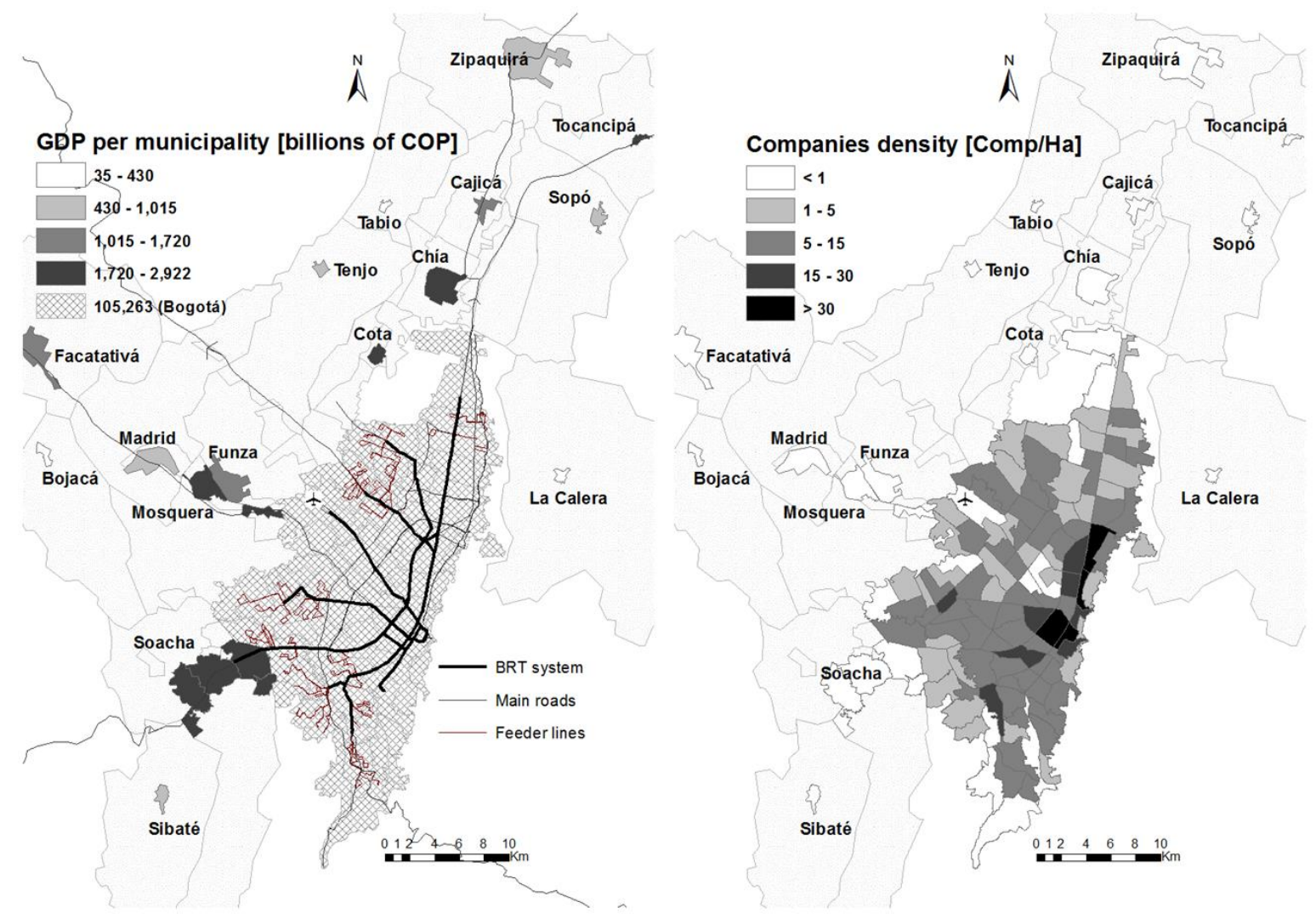

Figure 4. Economic information for Bogotá and its region

Source: elaboration by the authors using DANE and Bogotá Urban Planning Office data

This economic distribution also suggests a significant level of economic activity that is spatially concentrated in the cities of the west and the north of Bogotá. Thus, since the proximity to Bogotá allows for the expansion of municipal markets by reducing transport costs, the economic importance of the municipalities adjacent to the capital arises from their location within the system of regional transport.

\subsection{Functional structure, social and economic inequalities}

With regard to the transport system, the connection between Bogotá and its region is through roads, and there are severe congestion problems. There is no efficient public transport system in the region. Only the northern area of Soacha has a BRT connection (see Figure 4). The rest of this municipality and the other municipalities have different types of buses without identified stops, routes, and frequencies. According to the last mobility survey (SDM 2011), $86 \%$ of trips made in the municipalities involved Bogotá as origin or destination, whereas only $14 \%$ are made between municipalities. This confirms Bogotá as the city that carries the greatest importance in the BMA.

Given a history of greater autonomy and power for decision-making and investment for Bogotá, the development gap between the city and surrounding municipalities has grown, partly because of greater restrictions in the financial, political, and administrative levels. Increasing demographic and spatial pressure from its surroundings has granted greater importance to the creation of a metropolitan authority. In 1985, although Bogotá was the most populous city in the country, its proportion of the population with the surrounding 
municipalities was nine to one. However, over time and up to today, the relative population weight of Bogotá in the region has shown a slight decline. As shown in Figure 5, the BMA demographic trends are significant: the weight of the population of the capital decreases steadily from 8.5 to 1.5 in 2014. In fact, the rate of population growth in Bogotá over recent years was, on average, $1.5 \%$, whereas in the municipalities this was about $2.9 \%$.

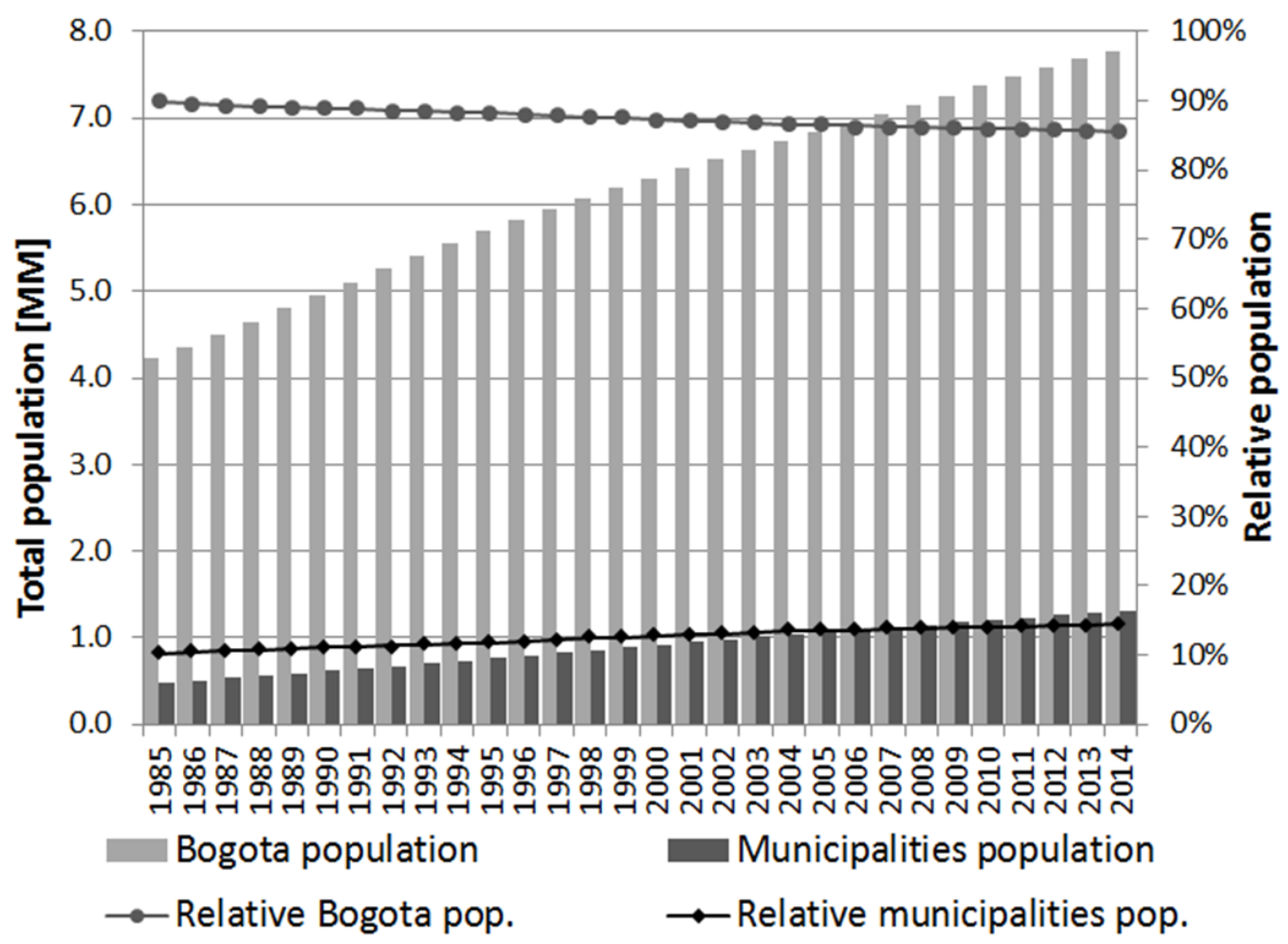

Figure 5. Evolution of the population in Bogotá and its region

Source: elaboration by the authors using DANE data

With respect to average income per household, Figure 6 shows the distribution of this indicator across the region. The data is in US dollars from 2011 when 1 USD $=1,900$ COP. Figure 6 (right) shows the zones with an average income below the average for the whole region (monthly USD 720 per household). As it can be seen, spatial segregation is widespread in the region with the majority of low-income zones located to the west and south of the city, and a segment in the north, whereas the highest income zones are north of the traditional downtown city centre. Most of the poorer areas had an informal origin: informal settlements in the periphery were the most common way of developing low-income housing (Skinner 2004).

Accordingly, most (around 85\%) of the household earnings of the BMA are below the average. This shows significant inequalities in income distribution: around $5 \%$ of the households have a monthly income above USD 2,100. According to the National Statistics Department (DANE), in 2013 the income distribution measured by the Gini index was 0.504 . 


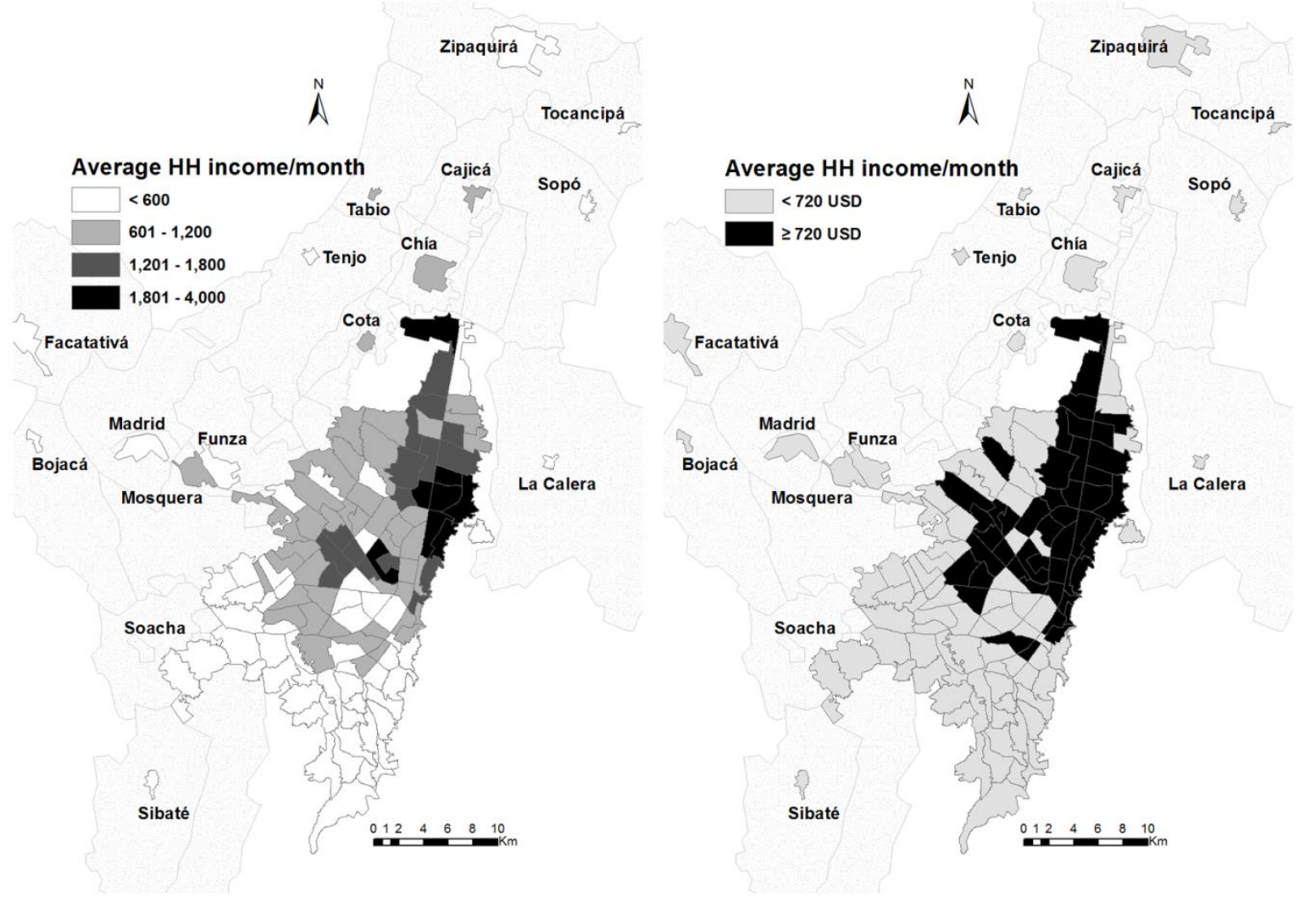

Figure 6. Average household income by zone (USD)

Source: elaboration by the authors from data of the mobility survey

The governance and administration of Bogotás urban development and its integration at the regional scale have influenced not only the distribution of the population in the region but the economic geography of the city, its concentration of production, and use of land. In the next sections we will use three main features to characterise the urban form of Bogotá at an aggregate level: the spatial structure (centralisation or spread), the identification of the main activity centres (seen as large concentrations of jobs), and the consumption of land.

\section{Defining the spatial form of the Bogotá Metropolitan Area}

The growth of the BMA during the last century was achieved organically, with uncoordinated policies between Bogotá and the surrounding municipalities. Urban development policies promoted growth in the region independently among municipalities and discouraged agreements for an integrated growth of the metropolitan area. This trend is unsustainable today.

The evolution of the spatial and socio-economic aspects of the BMA has important effects on the current configuration of the city-region. Thus, this section examines the performance of the BMA's urban spatial structure using empirical data obtained from mobility survey data and land-use plans. For simplicity of analysis we consider only three aspects of urban spatial structures: travel patterns, activity centres, and land consumption.

\subsection{Is the BMA monocentric or polycentric?}


The BMA has several urban centres but they do not all have the same hierarchy and very few of them have specialised economic structures. In addition, interaction between the municipalities is almost non-existent when compared with their interactions with the city of Bogotá. Here, the BMA is characterised as a large central place system, with the city of Bogotá as its main focus. This has a direct impact on travel patterns. A priori, it can be said that the BMA does not meet the basic concepts of a polycentric region (Parr 2004). We use the rank-size distribution ${ }^{2}$ of jobs in the BMA to assess the degree of functional polycentricity: the flatter the slope of this line, the more polycentric the region and, conversely, the steeper the slope of this line, the more monocentric the region (Meijers, Burger 2010).

According to Meijers (2008), the quantity of activity centres in the rank-size distributions is very important. In Bogotá city an employment zone of less than 20,000 workplaces may be insignificant, whereas it could be of great relative and absolute importance if the analysis is performed for the surrounding municipalities. Accordingly, we used two scales of analysis: the first relates to the BMA, and the second only to the city of Bogotá. The BMA is divided in 127 zones for this analysis, of which 112 zones are part of Bogotá city.

Figure 7 shows the zones and municipalities (in terms of quantity of jobs) in each of two scales, including the regression lines that best fit the rank-size distribution. The left side presents the 129 zones in the BMA, the other side the 112 zones (UPZ) in Bogotá and also the regression slopes that is best fit for the distributions of their sizes. These results show that the BMA and the city of Bogotá are predominantly monocentric (slopes of -1.56 and 1.14 respectively) when compared to regions in Europe (Veneri 2013, Burger, Meijers 2012, Adolphson 2009, Meijers 2008) and North America (Cowell 2010, Meijers, Burger 2010).
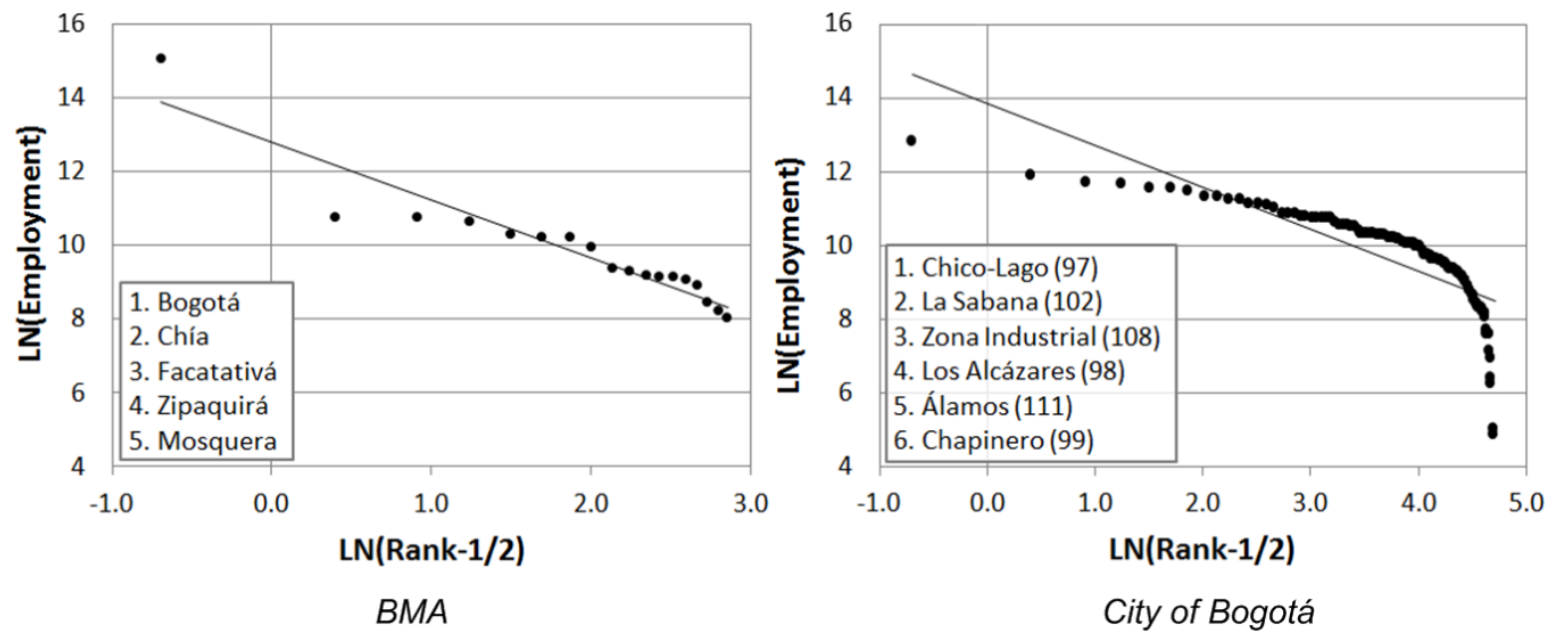

Figure 7. Rank-size distributions in the BMA and the city of Bogotá

Source: elaboration by the authors from data of the mobility survey

These results are on a scale ranging from a highly monocentric region to a monocentric city. The results differ somewhat from those of Dowall and Treffeisen (1991) who found that Bogotá is a multicentric city. Our hypothesis is that over the last 25 years these centres have been consolidated to form a single and large central core. A monocentric region/city

2 The main aim of this method is to identify regularities concerning the characteristics of settlements (in this case job concentration) in the zones belonging to BMA, and to fit a graphical description to the size distribution of zones. 
maintains a unified job concentration, allowing radial trips, from periphery to centre, which it is in fact what happens in BMA.

\subsection{Identifying main activity sub-centers}

Focusing on the city, the identification of more important activity centres provides a wider knowledge of the BMA's spatial organisation. A wide range of methods has been used to identify interurban sub-centres (Vasanen 2012, Roca Cladera, Marmolejo Duarte et al. 2009, Muniz, Galindo et al. 2003, Shearmur, Coffey 2002, Craig, Ng 2001, McMillen 2001, McDonald, Prather 1994, Dowall, Treffeisen 1991, Giuliano, Small 1991, McDonald 1987). Due to the level of spatial aggregation used in this paper, to identify a reference point we decided to use employment density to identify the most important sub-centres in the city, in this case we used UPZ \#93 (Chicó-Lago) as the Central Business District (CBD).

Two procedures for sub-centre identification are proposed here. One is related to previous works (Giuliano, Small 1991) based on hierarchical relations (employment and density thresholds) across all zones located within the city of Bogotá, which were adjusted according to the available data. The second is based on cubic spline ${ }^{3}$ density functions (Muniz, Galindo et al. 2003). In this case, a job density function relates gross employment density to distance to the CBD, and the estimated equation allows one to predict, the employment density for a specific distance from the CBD. This method has been criticised by some authors (Alperovich 1995) because it only has distance from the CBD as an explanatory variable; however, given the strategic level of this paper and the fact that Bogotá does not follow the usual density gradient (negative exponential function), it is considered acceptable by the authors.

With respect to the first approach, using the fixed thresholds from developed cities in Bogotá city does not seem to be a good idea. First, the thresholds are very sensitive to the spatial units of analysis, and second, there is the issue of data availability. As Veneri (2013) asserts, "the choice of thresholds is substantially arbitrary". For example, the employment gross density of 10 jobs per acre $\left(\approx 2,500\right.$ jobs $\left./ \mathrm{km}^{2}\right)$ is a very high threshold for Italian municipalities, but it is low compared to Bogotá where there are 67 zones with more than 20,000 workplaces and 122 zones with employment densities greater than 2,500 jobs/km².

Table 1 shows 16 zones with an employment density (including formal and informal employment) greater than 20,000 jobs $/ \mathrm{km}^{2}$, and it provides summary statistics. Figure 8 shows their locations. The most striking observation from Table 1 (and Figure 8) is the dominance of a large central core along major road corridors, and, especially, the northern part of the city centre (the wealthiest zones).

Table 1. Centres in order of employment density

\footnotetext{
3 According to Suits et al, (1978), cubic splines are a "device for approximating the shape of a curvilinear stochastic function without the necessity of pre-specifying the mathematical form of the function".
} 


\begin{tabular}{|c|c|c|c|c|c|}
\hline Zone & UPZ Name & $\begin{array}{c}\text { Employment } \\
\text { [No.] }\end{array}$ & $\begin{array}{c}\text { Employment } \\
\text { Density } \\
{\left[\text { jobs } / \mathbf{k m}^{2}\right]}\end{array}$ & $\begin{array}{c}\text { Employment/ } \\
\text { Population } \\
\text { ratio }^{\mathrm{a}}\end{array}$ & $\begin{array}{c}\text { Distance } \\
\text { from CBD } \\
{[\mathrm{km}]^{\mathrm{b}}}\end{array}$ \\
\hline $97^{c}$ & Chico-Lago & 362,020 & 85,696 & 14.7 & 2.1 \\
\hline 91 & Sagrado Corazon & 73,991 & 72,696 & 13.7 & 6.6 \\
\hline 99 & Chapinero & 99,812 & 63,057 & 5.2 & 4.1 \\
\hline $93^{d}$ & Las Nieves & 82,085 & 54,324 & 6.5 & 7.8 \\
\hline 105 & Jardin Botanico & 21,846 & 37,171 & 12.6 & 7.2 \\
\hline 108 & Zona Industrial & 119,239 & 34,571 & 30.5 & 8.4 \\
\hline 101 & Teusaquillo & 78,723 & 33,826 & 3.1 & 6.0 \\
\hline 102 & La Sabana & 145,285 & 32,766 & 3.0 & 8.0 \\
\hline 111 & Puente Aranda & 100,719 & 28,256 & 7.5 & 9.1 \\
\hline 98 & Los Alcazares & 113,742 & 27,665 & 1.5 & 2.7 \\
\hline 94 & La Candelaria & 49,991 & 24,651 & 2.3 & 9.5 \\
\hline 116 & Alamos & 47,461 & 23,868 & 3.7 & 9.0 \\
\hline 16 & Santa Barbara & 96,736 & 21,461 & 2.0 & 4.3 \\
\hline 21 & Los Andes & 58,824 & 21,405 & 1.4 & 3.3 \\
\hline 100 & Galerias & 49,342 & 20,973 & 1.5 & 4.5 \\
\hline 62 & Tunjuelito & 19,307 & 20,356 & 0.4 & 16.2 \\
\hline
\end{tabular}

a 16-65 years old population

${ }^{\mathrm{b}}$ Average travel distance in motorized modes

${ }^{c}$ CBD

d Traditional city centre

Source: elaboration by the authors

It is evident that in the city of Bogotá there is clustering of employment into a large core. Just over one-third of the city's employment occurs in zones occupying only $10 \%$ of its urban land area. In contrast, the estimated sub-centres in Mexico City account for less than $5 \%$ of its formal employment and less than $2 \%$ of the total number of jobs (Suárez, Delgado 2009). 


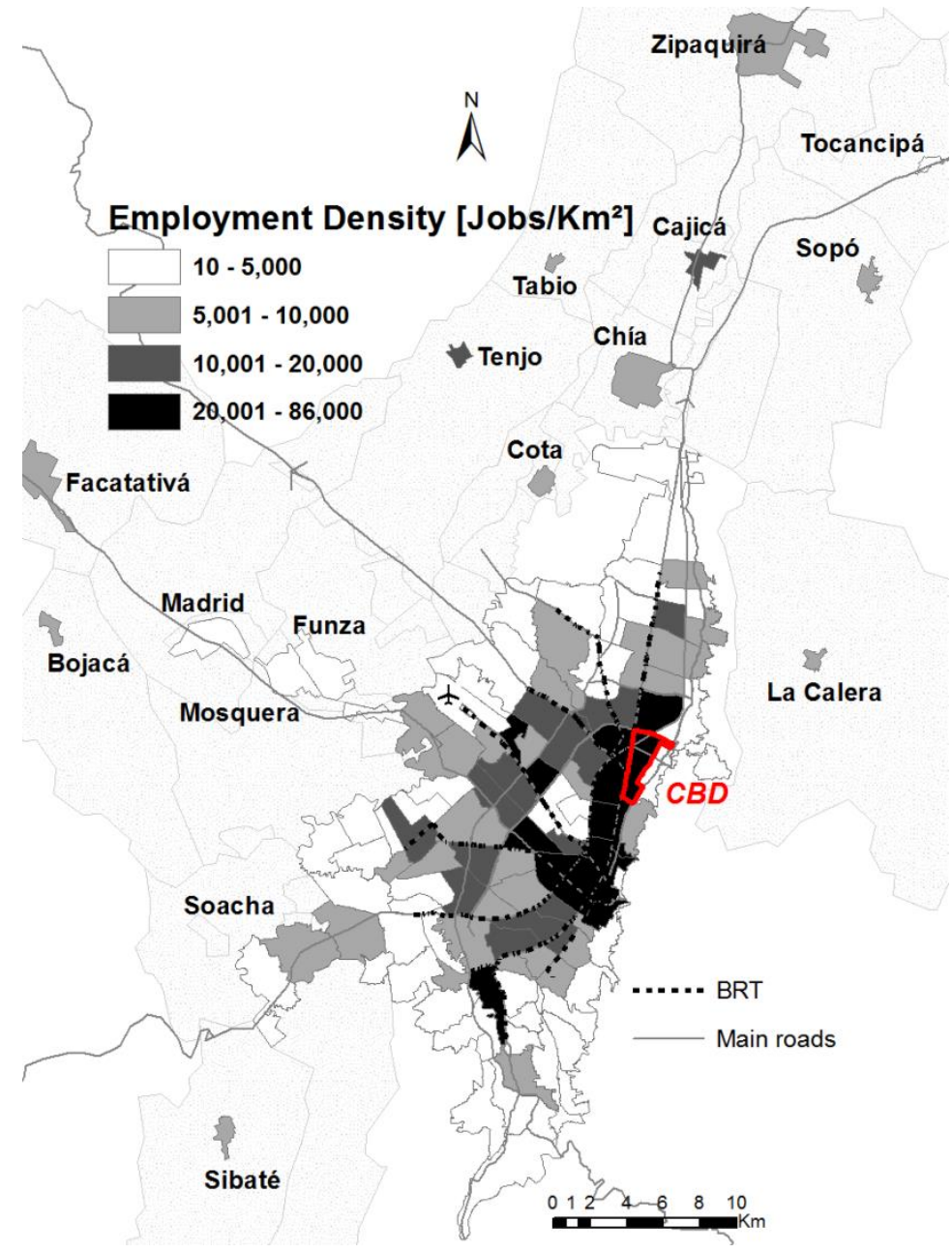

Figure 8. Employment density distribution

Source: elaboration by the authors

Although this method provides a fairly clear idea of the location of the major employment zones, the presence of dense peripheries (population) and sub-centres far from the CBD cannot be properly captured. Therefore, we propose an alternative method based on cubic spline functions. This method has been used in research applied to cities such as Detroit (Anderson 1985), Vancouver (Skaburskis 1989), Tokyo (Zheng 1991), Barcelona (Muniz, Galindo et al. 2003) and Paris (Gilli 2009), but never to a Latin American city.

The cubic spline estimation for Bogotá city considers six segments of the same length (3.65 $\mathrm{km})^{4}$. A cubic spline employment density function was estimated using the average travel distance to the CBD and the job density by zone. As can be seen in Figure 9, the cubic spline function fits better than the exponential function.

\footnotetext{
${ }^{4}$ This model was selected using the same criteria as Anderson (1985) and Muniz et al. (2003): the minimum standard error.
} 


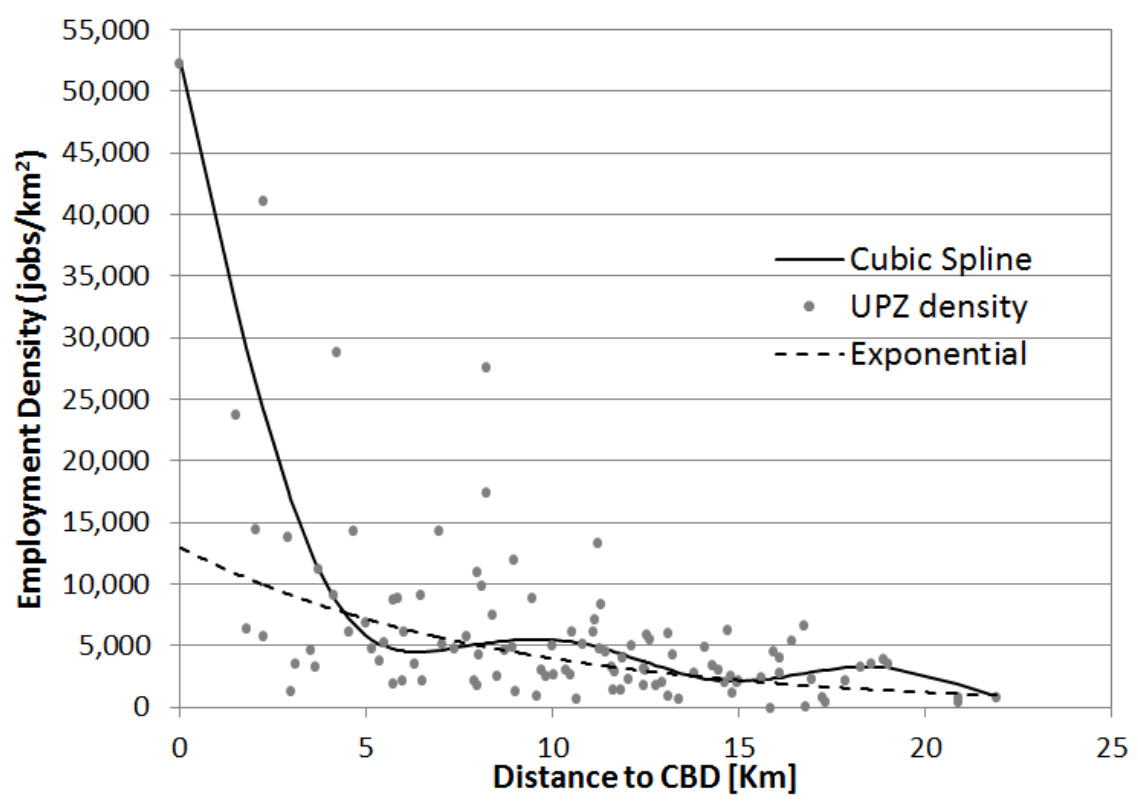

Figure 9. Estimates of the cubic spline density function for the city of Bogotá Source: elaboration by the authors

On average, and as shown in Figures 5 and 6 , it can be seen that the maximum height of the density function coincides with the CBD, which makes sense because this is the densest job zone. Thus, starting from the maximum, the density declines until a distance of $6 \mathrm{~km}$ is reached, where a local minimum appears. The density then increases again, but only slightly, reaching a local maximum around $10 \mathrm{~km}$ from the CBD where, on average, two important zones are identified: one, located to the south of the CBD (UPZ \#62), is characterised by a high share of the industrial sector and informal work. The second zone (UPZ \#105) is located to the west of the CBD and contains several metropolitan-scale city amenities, private companies, and a university. Finally, a new local peak appears around 19 $\mathrm{km}$ from the CBD but this is smaller than the others. This coincides with the northernmost area of the city, which is beginning to be transformed by new offices.

The dominance of a central core in Bogotá city (darker zones, Figure 8) is further illustrated by the travel distances. The average work travel distance to the CBD by zone origin is around $10.9 \mathrm{~km}$ and the average travel time in motorised transport modes is 48 minutes. This may indicate that most of the people who work in these areas live in different zones.

From the first method we identified 14 UPZ as a large central core of employment within the city of Bogotá in 2011. Consistent results were obtained with the cubic spline method: identifying a large core in which a large number of jobs are concentrated. We found that employment activity is mostly concentrated along a north-south linear core area, especially between the main roads and the BRT corridors.

Thus, employment is the key to understanding the formation of urban centres and it is now possible to conclude that the city of Bogotá has a large and main central core where employment is concentrated in an area of approximately $36 \mathrm{~km}^{2}$.

\subsection{Land consumption}

There are important differences in the population and activities location throughout BMA. There has been a highly unsatisfactory demand for low-cost housing that has encouraged 
people to occupy mostly unplanned and informal urban settlements. As a consequence, many informal neighbourhoods with poor urban living conditions have emerged on the outskirts of the city (see Figure 11). The densest sectors are located in the low-income zones near the southern and western borders of the urban area, where they can reach densities of up to $55,000 \mathrm{inh} / \mathrm{km}^{2}$, and both are in consolidated zones of generally informal origin (Paez, Bocarejo et al. 2014). In contrast, the northern CBD and central locations are characterised by high-rise developments, high formal employment concentration, and lower population densities. In these locations they exist alongside commercial activities, services and offices, and have densities of between 6,000 and 15,000 inh/ $/ \mathrm{km}^{2}$. Figure 10 (left) shows that the highest densities are located in the southern (west and east) and north-western parts of the city, whereas the lower densities are in the northern part of the city, which also has the highest proportion of high-rise buildings and high-income population.

With regard to the urban built environment, Figure 10 (right) shows a city characterised by low-rise buildings and reduced green space (the green areas only represent $8 \%$ of the city and consist of approximately $4.3 \mathrm{~m}^{2} / \mathrm{inh}$, whereas the World Health Organization recommends $10-15 \mathrm{~m}^{2} / \mathrm{inh}$ ). The most densely built up areas are the zones of lowest population density.

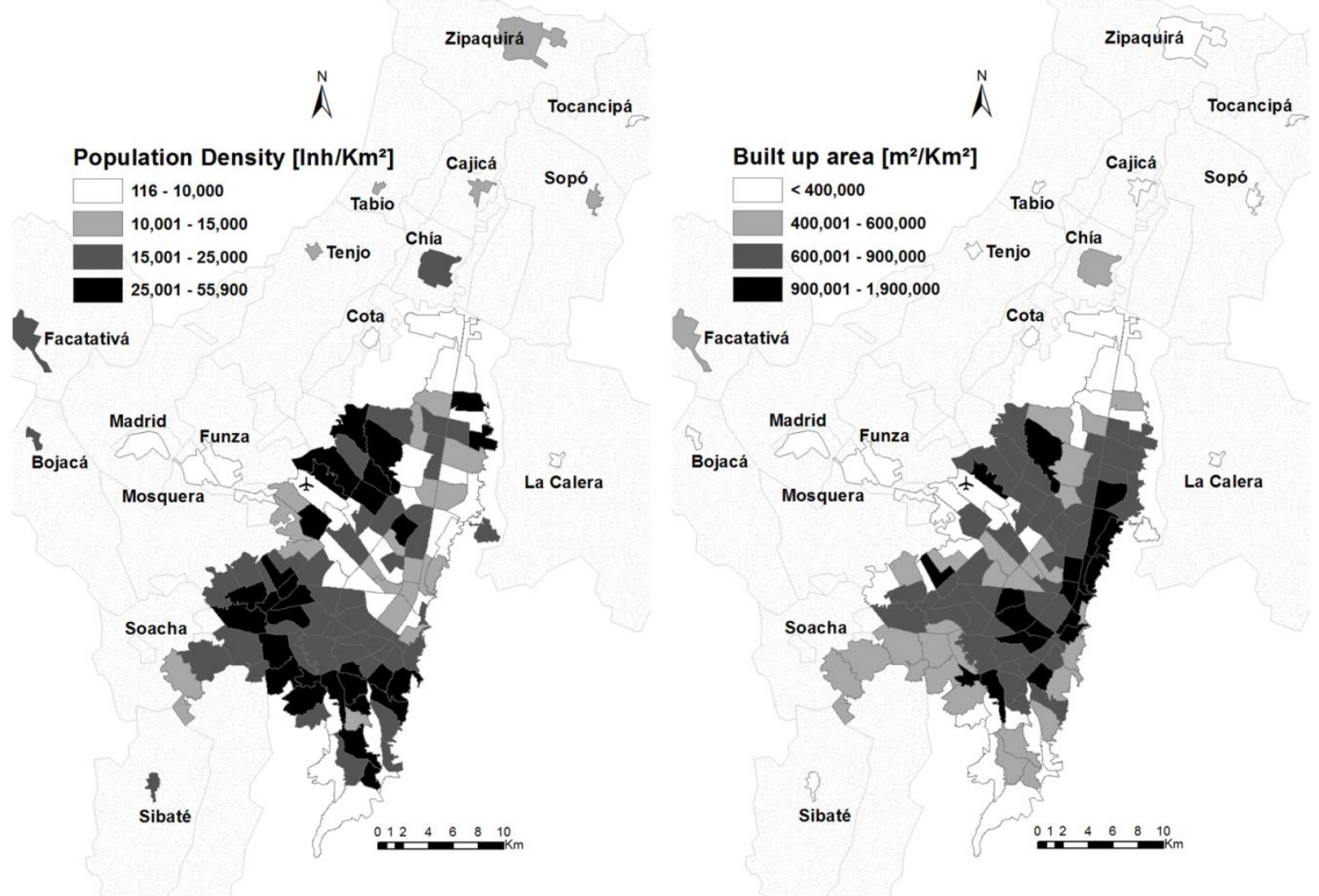

Figure 10. Population density and built up area density distribution

Source: elaboration by the authors

Different income groups have different density levels. The "low-income density" has an average of 23,100 inhabitants per $\mathrm{km}^{2}$ and is composed mainly of low built-up areas, that is, neighbourhoods predominately characterised by residential and low-rise developments without public spaces, roads, and green areas; this corresponds with the type of illegal 
settlements that are located on the outskirts of the city. The medium-income group presents a lower average density (around 12,700 inh $/ \mathrm{km}^{2}$ ) with larger areas of buildings, more floors, fewer residential neighbourhoods, and a larger built-up area per person. The "high-income density" presents low densities of about $7,500 \mathrm{inh} / \mathrm{km}^{2}$ with higher land values and the highest building area. More information about densities in Bogotá is available in Paez et al. (2014).

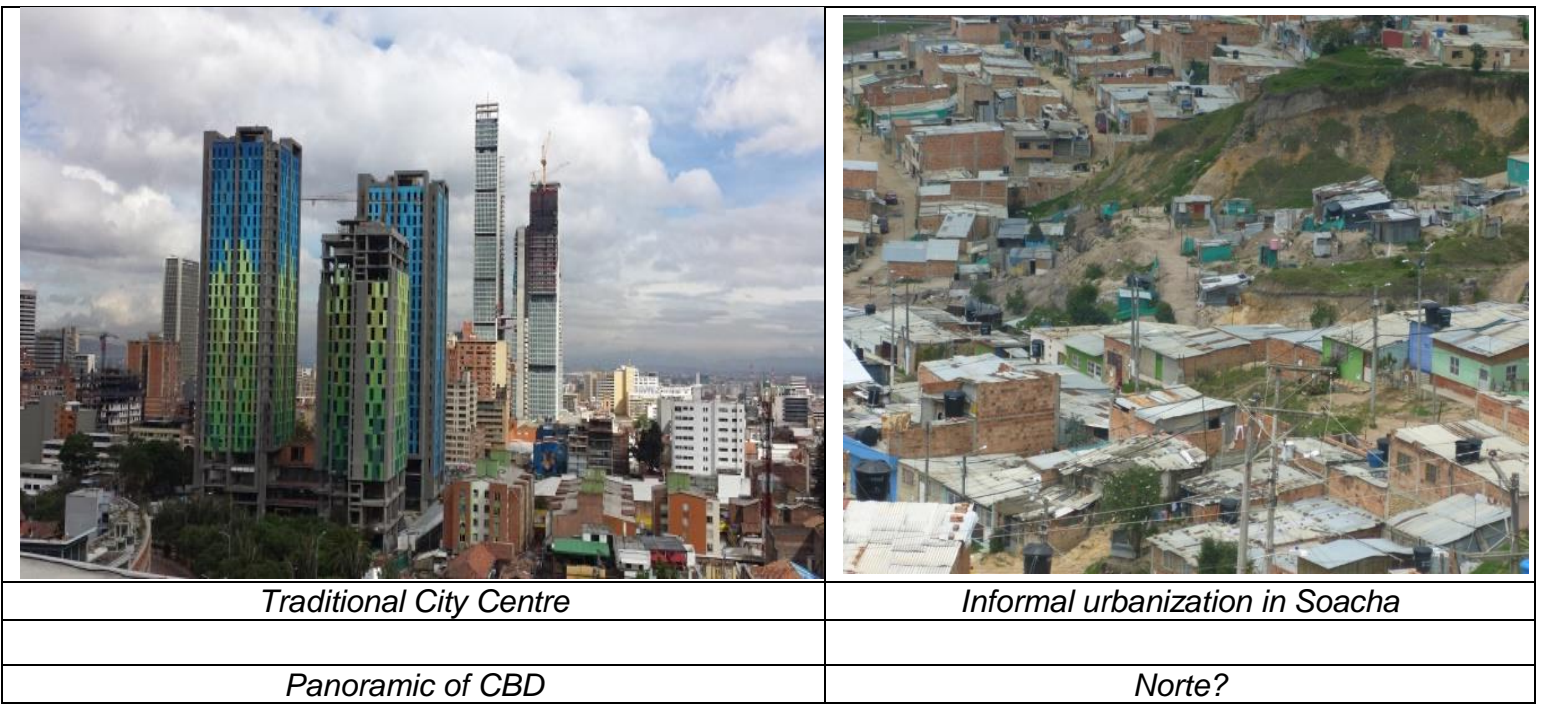

Figure 11. Land consumption and urban environmental in Bogotá

Source: elaboration by the authors

Figure 12 shows the evolution of some of the indicators of Bogotá: showing population, urban land, and density since 1938. As the urban land has grown more slowly than the population, particularly since the 1970 s, the resulting average population density has increased (1.5 times).

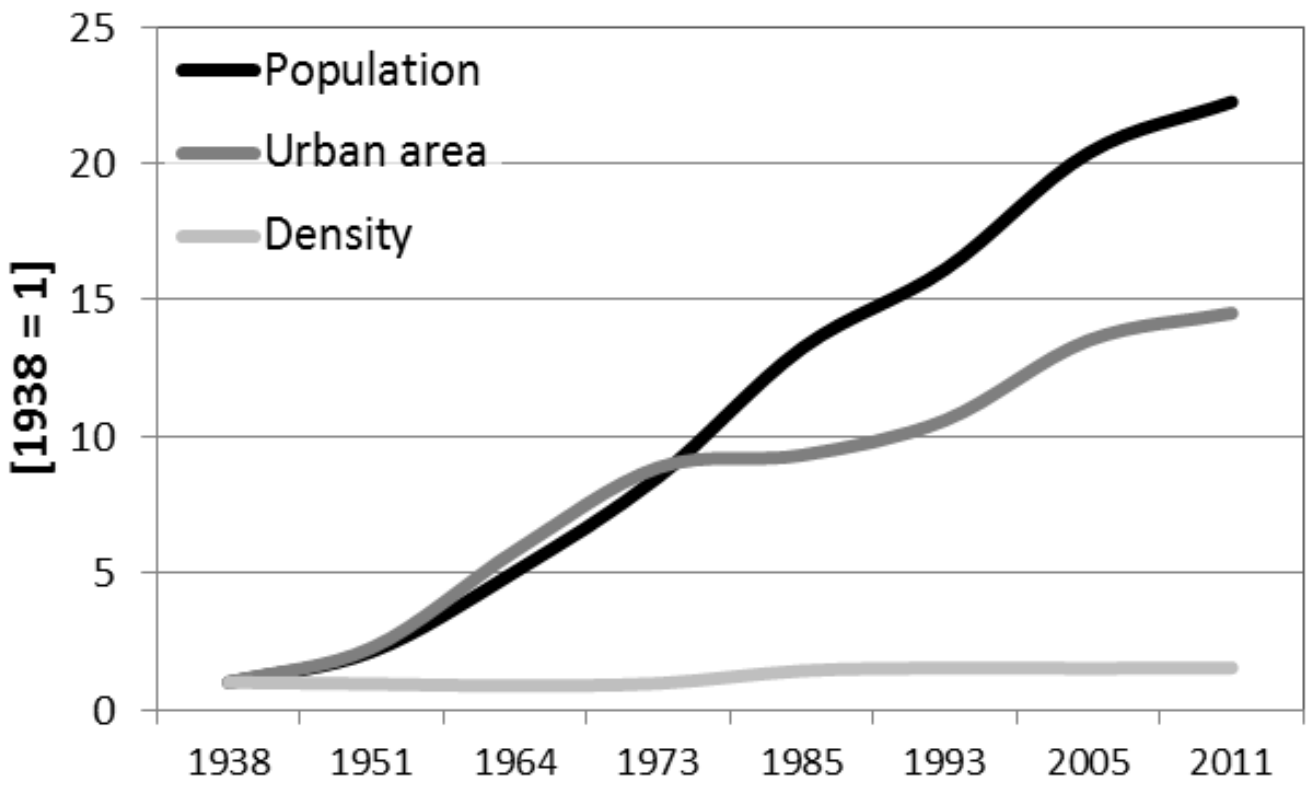

Figure 12. Evolution of population, urban land and density (1938-2011)

Source: elaboration by the authors 
Around the 1970s and 80s, the central areas of the city began to lose population despite the replacement of old houses by taller buildings. Meanwhile, the urban periphery experienced a more dynamic growth, particularly in the south and west areas of the city, giving rise to vast high-density residential areas.

Although high densities can have many advantages with regard to transport (Tong, Wong 1997), in Bogotá the people who live in the densest zones have to travel longer distances in their commutes because most of the jobs are not within these zones (or near them). Another issue is car ownership. Automobile access is usually a major topic in equity discussions, despite the fact that intensive car use is linked to low-density patterns and urban sprawl.

Unfortunately, this rapid growth has coincided with the absence of a strong and effective institutional framework able to guide the evolution of the city and the region. Economic and technical resources have been insufficient to meet the growing demands for goods and services for the population, which, despite the good economic environment, has led to a gradual deterioration in social cohesion and equity.

\section{Conclusions}

Demographic growth, urban expansion, and development in Bogotá and its surrounding region have created a spatial and functional structure that has long since surpassed the administrative borders of both the city and the individual municipalities. These dynamics are underpinned by the absence of a legal, regulatory, and institutional framework that can support inter-municipal coordination and joint development. The organic growth of each municipality in the region has carried implications in relation to the social, spatial, and economic inequalities that stem from fragmented urban development in the (legally inexistent) BMA. This has led to the consolidation of premium land, infrastructure, and supply of opportunities at the centre of the city, whereas wealth, production, and housing in adjacent municipalities has followed a distribution that mimics the socio-spatial structure of Bogotá, consolidating inequalities already marked within the city.

Historic milestones in the governance of the country, and the specific conditions granted for Bogotá by the Constitution and the legal instruments, have created a gap between the city and the adjacent municipalities that has reduced interest from all sides in pursuing the creation of a metropolitan authority. The expansion of the city's borders in the 1950s supplied sufficient land for Bogotá's expansion and development for decades before reaching its limits. This had a visible effect on the consolidation of high densities in the city, as well as on the increase in informal development in peripheral areas and municipalities such as Soacha. However, in largely populated municipalities, institutional weakness, financial constraints, corruption, and other structural problems have constrained compliance with the minimum requirements to implement actions identified by their POTs, to follow the recommendations of the different initiatives for regional development, or the guidelines from national policies. Lack of an urban metropolitan authority, or at least a legitimate functional urban area, makes it almost impossible to integrate the municipalities in the Bogotá cityregion through investments in transport. The National Urban Transport Policy defines the institutions that manage urban public transport systems as municipal entities and, as such, they are limited by the planning, implementation, and operation of services outside their jurisdiction. This presents a great challenge for the use of transport as an instrument for regional planning and integration in the context of Bogotá and its surrounding municipalities.

Figures related to the spatial distribution of activities in the region reflect the consolidation of Bogotá's urban primacy, concentrating a large share of the BMA's supply of employment 
in the region. In addition, following a similar socio-spatial distribution to Bogotá, greater availability of land and supply for both formal and informal housing has led to an increase in the urban population (both higher and lower income) in neighbouring municipalities and has thus strengthened social inequalities in the region. Lack of housing supply and connectivity services in the city are linked with lack of regional coordination and the lack of a framework for metropolitan development and the administration of land use. The end result is the consolidation of social inequalities in relation to travel conditions (cost and time) and access to housing for the poor, with high densities and poor quality leading to deterioration in the quality of life for low-income populations in the BMA.

Evidence presented in this paper suggests the relevance of an institutional and governance framework for coordinating regional development in a context of administrative decentralisation and large urban primacy, as is the case in many capital and large cities in Latin America. Although the development of the BMA has served the region's demographic and economic needs, this organic development has influenced the distributional effects of urbanisation. This carries lessons for Bogotá's future urban planning and for that of other cities facing similar challenges in the Global South. The reproduction of social and spatial inequalities is related to the lack of a comprehensive regulatory framework at the metropolitan level and the formal and informal consolidation of Bogotá's vicinity within a market logic that reproduces already high levels of spatial and social segregation in the city. This speaks to all levels of governance of urban areas in the country. In order to address this physical and institutional fragmentation a solid legal framework is required at the national level, considerations for managing decentralisation at the sub-national level, and spaces for reaching agreements and for strengthening representation at the local scale.

The rapid development of the city and the consolidation of its economy, as well as more serious recent initiatives for regional integration, suggest positive trends in Bogotá's future development. Further research on the city needs to account for changes at all levels of demographics, urban development, and the economy. This needs to be undertaken without losing sight of emerging changes in local and metropolitan governance. Due to the imminent signing of a peace treaty with the guerrilla movement, FARC, that will put an end to a longstanding conflict that has displaced millions from the country to the cities, local and national conditions suggest a potential decrease in forcibly displaced populations. The second term of Enrique Peñalosa and further governments will challenge the notions of appropriateness and sustainability of infrastructure investments such as BRT and other transport infrastructure that have made Bogotá prominent in recent decades. Similarly, analysis of urban consolidation, social segregation and exclusion, and the reduction in poverty will inform further planning in other cities in the region.

\section{References}

ACEVEDO, J., VELÁSQUEZ, J.M. and BOCAREJO, J.P., 2012. La promesa presidencial de un cable aéreo: limitaciones institucionales y realidades políticas. In: J.D. DÁVILA, ed, Movilidad Urbana y Pobreza: Aprendizajes de Medellín y Soacha, Colombia. London: Development Planning Unit, UCL, and Universidad Nacional de Colombia, pp. 130-136.

ACOSTA, P., 2010. The Bogota - Sabana Region: The political economy behind the struggle to implement a sustainable urban development model. 32. Universidad del Rosario. 
ADOLPHSON, M., 2009. Estimating a Polycentric Urban Structure. Case Study: Urban Changes in the Stockholm Region 1991-2004. Journal of Urban Planning and

Development, 135(1), pp. 19-30.

ALPEROVICH, G., 1995. The Effectiveness of Spline Urban Density Functions: An Empirical Investigation. Urban Studies, 32(9), pp. 1537-1548.

ANDERSON, J.E., 1985. The changing structure of a city temporal changes in cubic spline urban density patterns. Journal of Regional Science, 25(3), pp. 413-425.

ANGULO SALAZAR, R.C., DÍAZ, B.Y. and PARDO PINZÓN, R., 2013. A Counting Multidimensional Poverty Index in Public Policy Context: The Case of Colombia. 62. University of Oxford.

BORSDORF, A. and HIDALGO, R., 2010. From Polarization to Fragmentation. Recent Changes in Latin American Urbanization. In: P. LINDERT and O. VERKOREN, eds, Decentralized Development in Latin America: Experiences in Local Governance and Local Development. Dordrecht: Springer Netherlands, pp. 23-34.

BOTERO, M.H. and SUÁREZ, C., 2010. Bogotá y la descentralización intraterritorial: crónica de una historia inconclusa. 37. Universidad del Rosario.

BURGER, M. and MEIJERS, E., 2012. Form Follows Function? Linking Morphological and Functional Polycentricity. Urban Studies, 49(5), pp. 1127-1149.

CARTER, J., 2003. Neoliberal economic reforms and urban sociospatial change in Latin America: The case of La Serena-Coquimbo, Chile. University of California, Santa Barbara and San Diego State University.

CORTÉS, M.E., 2005. La anexión de los 6 municipios vecinos a Bogotá en 1954 "Un hecho con antecedentes". Revista Bitácora Urbano Territorial, 9(1), pp. 122-127.

COWELL, M., 2010. Polycentric Regions: Comparing Complementarity and Institutional Governance in the San Francisco Bay Area, the Randstad and Emilia-Romagna. Urban Studies, 47(5), pp. 945-965.

COY, M., 2006. Gated communities and urban fragmentation in Latin America: the Brazilian experience. GeoJournal, 66(1), pp. 121-132.

CRAIG, S.G. and NG, P.T., 2001. Using Quantile Smoothing Splines to Identify Employment Subcenters in a Multicentric Urban Area. Journal of Urban Economics, 49(1), pp. 100-120.

DANE, 2013-last update, Históricos Producto Interno Bruto-PIB. Available: http://www.dane.gov.co/index.php/pib-cuentas-nacionales/cuentas-anuales/109boletines/cuentas-y-sintesis-nacionales/2756-producto-interno-bruto-pib2016].

DÁVILA, J.D., 2009. Being a mayor: the view from four Colombian cities. Environment and Urbanization, 21(1), pp. 37-57. 
DÁVILA, J.D., 2005. La transformación de Bogotá. In: F. CEPEDA ULLOA, ed, Fortalezas de Colombia. Bogotá: Editorial Planeta, pp. 418-439.

DÁVILA, J.D., GILBERT, A., BRAND, P., RUEDA, N. and COUPE, F., 2006. Housing and land for the urban poor. Case studies of Bogotá-Soacha and Medellín. Bogota, Colombia: .

DOWALL, D.E. and TREFFEISEN, P.A., 1991. Spatial transformation in cities of the developing world: Multinucleation and land-capital substitution in Bogotá, Colombia. Regional Science and Urban Economics, 21(2), pp. 201-224.

GILBERT, A., 2015. Urban governance in the South: How did Bogotá lose its shine? Urban Studies, 52(4), pp. 665-684.

GILBERT, A., 2008. Bus Rapid Transit: Is Transmilenio a Miracle Cure? Transport Reviews, 28(4), pp. 439-467.

GILBERT, A. and VARLEY, A., 1990. Renting a home in a third world city: choice or constraint? International Journal of Urban and Regional Research, 14(1), pp. 89-108.

GILLI, F., 2009. Sprawl or Reagglomeration? The Dynamics of Employment Deconcentration and Industrial Transformation in Greater Paris. Urban Studies, 46(7), pp. $1385-1420$.

GIULIANO, G. and SMALL, K.A., 1991. Subcenters in the Los Angeles region. Regional Science and Urban Economics, 21(2), pp. 163-182.

HALSETH, G., 2005. Redrawing Local Government Boundaries: An International Study of Politics, Procedures, and Decisions. International Journal of Urban and Regional Research, 29(2), pp. 466-468.

HIDALGO, D. and SANDOVAL, E., 2004. TransMilenio: A High Capacity - Low Cost Bus Rapid Transit System Developed for Bogotá, Colombia. American Society of Civil Engineers, pp. 37-49.

HURTADO, A., HENÁNDEZ, M. and MIRANDA, L., 2014. Gestión de grandes proyectos urbanos en espacios metropolizados: Los sistemas integrados de transporte masivo en Colombia. Bogotá: Universidad Piloto de Colombia, Grupo de Investigación de la Maestría en Gestión Urbana.

JANOSCHKA, M. and BORSDORF, A., 2006. Condominios fechados and barrios privados: the rise of private residential neighbourhoods in Latin America. In: G. GLASZE, C. WEBSTER and K. FRANTZ, eds, Private Cities. Global and local perspectives. London: Routledge, pp. 89-104.

LIBERTUN DE DUREN, N., 2006. Planning à la Carte: The Location Patterns of Gated Communities around Buenos Aires in a Decentralized Planning Context. International Journal of Urban and Regional Research, 30(2), pp. 308-327. 
LOW, N. and ASTLE, R., 2009. Path dependence in urban transport: An institutional analysis of urban passenger transport in Melbourne, Australia, 1956-2006. Transport Policy, 16(2), pp. 47-58.

MCDONALD, J.F., 1987. The identification of urban employment subcenters. Journal of Urban Economics, 21(2), pp. 242-258.

MCDONALD, J.F. and PRATHER, P.J., 1994. Suburban Employment Centres: The Case of Chicago. Urban Studies, 31(2), pp. 201-218.

MCMILLEN, D.P., 2001. Nonparametric Employment Subcenter Identification. Journal of Urban Economics, 50(3), pp. 448-473.

MEIJERS, E., 2008. Measuring Polycentricity and its Promises. European Planning Studies, 16(9), pp. 1313-1323.

MEIJERS, E. and BURGER, M., 2010. Spatial structure and productivity in US metropolitan areas. Environment and Planning A, 42(6), pp. 1383-1402.

MIRANDA, L., 2008. La gestión urbana en la ciudad colombiana. Una agenda por construir y unos logros por consolidar. Bogotá: Universidad Piloto de Colombia, Grupo de Investigación de la Maestría en Gestión Urbana.

MONTEZUMA, R., 2000. Presente y futuro de la movilidad urbana en Bogotá: retos y realidades. Bogotá: Veeduria Distrital.

MONZÓN, A., 2005. Gestión del transporte metropolitano. In: J.R. CUADRADO-ROURA, J.M. FERNÁNDEZ GÜELL and E. ROJAS, eds, Gobernar las metrópolis. Washington, DC: Banco Interamericano de Desarrollo, pp. 409-472.

MUNIZ, I., GALINDO, A. and GARCIA, M.A., 2003. Cubic Spline Population Density Functions and Satellite City Delimitation: The Case of Barcelona. Urban Studies, 40(7), pp. 1303-1321.

NICKSON, R.A., 1995. Local Government in Latin America. Boulder, CO: Lynne Rienner Publishers.

PAEZ, D., BOCAREJO, J.P., GUZMAN, L.A., PORTILLA, I., MELENDEZ, D. and CAVIEDES, A., 2014. To densify or to not densify? Mobility and urban life in a developing city, , June 2014, XVIII Pan-American Congress of Traffic, Transport and Logistics.

PARDO, C.I. and ALFONSO, W.H., 2013. Effects of Urbanisation and Suburbanisation on Health in the Bogotá Region. In: A. COTTE and C.I. PARDO, eds, Health, Violence, Environment and Human Development in Developing Countries. New York: Nova, pp. 147164.

PARR, J., 2004. The Polycentric Urban Region: A Closer Inspection. Regional Studies, 38(3), pp. 231-240. 
ROCA CLADERA, J., MARMOLEJO DUARTE, C.R. and MOIX, M., 2009. Urban Structure and Polycentrism: Towards a Redefinition of the Sub-centre Concept. Urban Studies, 46(13), pp. 2841-2868.

SALAZAR-FERRO, J., 2007. La planeación de Bogotá: un sistema híbrido de desarrollo progresivo. Revista Bitácora Urbano Territorial, 11(1), pp. 208-219.

SALAZAR-FERRO, J., GARCÍA BOCANEGRA, J.C., FRETES CIBILS, V., TORRES ARZAYÚS, P., VALLEJO DE LA PAVA, ADRIANA, PINTO CARRILLO, A.C. and GALLO P., I., 2010. Las ciudades del mañana: Gestión del suelo urbano en Colombia. Torres Arzayús, Patricia;García Botero, María Constanza edn. Washington, D.C.: Inter-American Development Bank.

SDM. Encuesta de Movilidad de Bogotá 2011. Informe de Indicadores. Bogotá: Secretaría de Movilidad de Bogotá; 2011.

SHEARMUR, R. and COFFEY, W.J., 2002. A tale of four cities: intrametropolitan employment distribution in Toronto, Montreal, Vancouver, and Ottawa - Hull, 1981 - 1996. Environment and Planning A, 34(4), pp. 575-598.

SKABURSKIS, A., 1989. Inversions in Urban Density Gradients: A Brief Look at the Vancouver Metropolitan Area's Density Profile. Urban Studies, 26(4), pp. 397-401.

SKINNER, R., 2004. City profile Bogotá. Cities, 21(1), pp. 73-81.

SUÁREZ, M. and DELGADO, J., 2009. Is Mexico City Polycentric? A Trip Attraction Capacity Approach. Urban Studies, 46(10), pp. 2187-2211.

SUITS, D.B., MASON, A. and CHAN, L., 1978. Spline Functions Fitted by Standard Regression Methods. The review of economics and statistics, 60(1), pp. 132-139.

THIBERT, J. and OSORIO, G.A., 2014. Urban Segregation and Metropolitics in Latin America: The Case of Bogotá, Colombia. International Journal of Urban and Regional Research, 38(4), pp. 1319-1343.

TONG, C.O. and WONG, S.C., 1997. The advantages of a high density, mixed land use, linear urban development. Transportation, 24(3), pp. 295-307.

VASANEN, A., 2012. Functional Polycentricity: Examining Metropolitan Spatial Structure through the Connectivity of Urban Sub-centres. Urban Studies, 49(16), pp. 3627-3644.

VENERI, P., 2013. The identification of sub-centres in two Italian metropolitan areas: A functional approach. Cities, 31(0), pp. 177-185.

VILLARRAGA, H.G., 2015. Migración interna, movilidad residencial y dinámicas metropolitanas en Colombia, Centre d'Estudis Demogràfics, Universitat Autonoma de Barcelona. 
WATSON, V., 2009. 'The planned city sweeps the poor away...': Urban planning and 21 st century urbanisation. Progress in Planning, 72(3), pp. 151-193.

WORLD BANK, 2009. World Development Report 2009 : Reshaping Economic Geography. World Bank.

ZHENG, X., 1991. Metropolitan Spatial Structure and its Determinants: A Case-study of Tokyo. Urban Studies, 28(1), pp. 87-104. 